


\section{THE LEFT IN FRANCE}

Neill Nugent

Senior Lecturer in Politics at Manchester Polytechnic

and

\section{David Lowe}

Member of the cabinet of Pieter Dankert,

President of the European Parliament

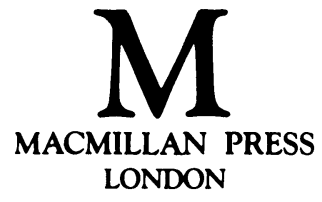


(C) Neill Nugent and David Lowe 1982

All rights reserved. No part of this publication may be reproduced or transmitted, in any form or by any means, without permission

First edition 1982

Reprinted 1983

Published by

THE MACMILLAN PRESS LTD

London and Basingstoke

Companies and representatives

throughout the world

ISBN 978-0-333-24135-6 (hardcover)

ISBN 978-0-333-35445-2 ISBN 978-1-349-06868-5 (eBook)

DOI 10.1007/978-1-349-06868-5 


\section{Contents}

Preface vii

Acknowledgements $\quad$ ix

List of Abbreviations $\quad$ x

PART I THE HISTORICAL INHERITANCE

1 What is the Left? 3

2 The Development of the Modern Political Parties of the Left

PART II THE PARTIES OF THE LEFT

3 The Socialist Party 47

4 The Communist Party 94

5 The Left in the Fifth Republic: the Struggle for Unity 147

6 The Alternative Left 179

PART III THE INFLUENCE OF THE LEFT

7 The Left in the Political System 195

8 The Left at Local Level 199

9 The Trade Unions and the Left 212

Postscript: The Left and the Assumption of Power 236

Appendixes

1 Parliamentary Election Results in the Fifth Republic, 1958-78 
2 Presidential Election Results in the Fifth Republic 253

3 European Election Results 1979

4 Parliamentary Election Results, June $1981 \quad 254$

5 The Background of Voters in March $1978 \quad 255$

6 Extracts from Declaration Made by PS and PCF, 23 June 1981

Notes and References $\quad 258$

Select Bibliography $\quad 270$

Index 272 


\section{Preface}

After being in permanent opposition since the Fifth Republic was established in 1958 the French Left returned to office in 1981. Moreover it did so in a spectacular manner. François Mitterrand became, in May, the first candidate of the Left ever to be elected to the presidency by universal suffrage. In June, in the legislative elections which Mitterrand called, the Socialists won an overall parliamentary majority for the first time in their history. The Left as a whole gained more parliamentary seats than it had won even at the times of the Popular Front or the Liberation. The elections of 1981 were, in short, truly historic.

The major purpose of our book is to provide a comprehensive study of the Left in France. The book falls into three parts. In the first we define and discuss the historical inheritance of the contemporary Left. In the second the political parties of the modern Left are analysed. Finally, in the third part we show that despite its long absence from national office the Left in the Fifth Republic has nonetheless exercised considerable influence in modern France. Even now that it is in government the power of the Left at local level and in the trade union movement should not be overlooked.

It should be explained that this book was initially completed in mid-1980. Proofs arrived, inconveniently for us, shortly after Mitterrand's election. After discussions with Macmillan Press it was agreed to update the text where that seemed necessary and to add an extensive Postscript which would look in some detail at the circumstances of the 1981 upheaval. These two tasks obviously necessitated considerable changes being made to the proofs and we would particularly like to thank Tim Farmiloe and Tim Fox of Macmillan for enabling us to make them.

Many officials and representatives of Left-wing parties and groups assisted us in our research and to them we give our thanks. The unsung heroes of academic research - the librarians - have, as always, played their part and to them we also owe many debts. Neill Nugent would like to thank the Nuffield Foundation (Small Grants Scheme) 
viii

for providing financial assistance to visit France and David Lowe thanks the Politics Department of Lancaster University for giving similar help. For reading and offering valuable comments on drafts of the manuscript we are grateful to John Frears, Peter Marsh and Vincent Wright. Finally our thanks go to Maureen Nugent for typing and retyping the manuscript.

July 1981

NEILL NUGENT

DAVID LOWE 


\section{Acknowledgements}

The author and publishers wish to thank the following who have kindly given permission for the use of copyright material:

Presses de la Fondation Nationale des Sciences Politiques for two charts from Revue Française de Science Politique, no. 5, October 1978, and no. 6, December 1978;

C. Hurst and Co. (Publishers) for the table from J. R. Frears and J. L. Parodi, War Will Not Take Place;

Le Nouvel Observateur for the chart from their issue of 23 April 1978;

Vincent Wright for the table from his book The Government and Politics of France.

Every effort has been made to trace all the copyright holders but if any have been inadvertently overlooked the publishers will be pleased to make the necessary arrangement at the first opportunity. 


\section{List of Abbreviations}

ANECR Association nationale des élus communistes et républicaines

BCEN Banque commerciale pour l'Europe du Nord

CD Centre Démocrate

CDP Centre Dèmocratie et Progrès

CERES Centre d'Etudes de Recherches et d'Education Socialiste

CFDT Confédération Française Démocratique du Travail

CFTC Confédération Française des Travailleurs Chrétiens

CGC Confédération Générale des Cadres

CGT Confederation Générale du Travail

CGTU Confédération Générale du Travail Unitaire

CIR Convention des Institutions Républicaines

EEC European Economic Community

FA Front Autogestionnaire

FEN Fédération de l'Education Nationale

FGDS Fédération de la Gauche Démocrate et Socialiste

FNESR Fédération nationale des élus socialistes et républicaines

FO Force Ouvrière

GEARS Groupe d'Etude et d'Action Radical-Socialiste

IFOP Institut Français d'Opinion Publique

ISER Institut Socialiste d'Etudes et de Recherche

JCR Jeunesse Communiste Révolutionnaire

LCR Ligue Communiste Révolutionnaire

LO Lutte Ouvrière

MJCF Mouvement de la jeunesse communiste de France

MRG Mouvement des Radicaux de Gauche

MRP Mouvement Républicain Populaire

PCE Partido Communista de España

PCF Parti Communiste Français

PCI Partito Communista Italiano

PCMLF Parti Communiste Marxiste-Léniniste de France

PCR Parti Communiste Révolutionnaire (Marxiste-Léniniste)

PDM Progrès et Démocratie Moderne 


$\begin{array}{ll}\text { PS } & \text { Parti Socialiste } \\ \text { PSA } & \text { Parti Socialiste Autonome } \\ \text { PSU } & \text { Parti Socialiste Unifié } \\ \text { RFSP } & \text { Revue Française de Science Politique } \\ \text { RI } & \text { Républicains Indépendants } \\ \text { RPR } & \text { Rassemblement pour la Republique } \\ \text { SFIO } & \text { Section Française de l'Internationale Ouvrière } \\ \text { SMC } & \text { State Monopoly Capitalism } \\ \text { SPD } & \text { Sozialdemokratische Partei Deutschlands } \\ \text { UCRG } & \text { Union des Clubs pour le Renouveau de la Gauche } \\ \text { UDF } & \text { Union pour la Démocratie Française } \\ \text { UDSR } & \text { Union Démocratique et Socialiste de la Résistance } \\ \text { UEC } & \text { Union des Etudiants Communistes } \\ \text { UGCS } & \text { Union des Groupes et Clubs Socialistes } \\ \text { UGS } & \text { Union de la Gauche Socialiste } \\ \text { UGSD } & \text { Union de la Gauche Socialiste et Démocratique } \\ \text { UJCML } & \text { Union des Jeunesses Communistes Marxistes-Léninistes } \\ \text { UNEF } & \text { Union Nationale des Etudiants Français } \\ \text { UNR } & \text { Union pour la Nouvelle République }\end{array}$

